\title{
FAMILY OWNERSHIP AND FIRM PERFORMANCE: ROMANIA VERSUS GERMANY
}

\author{
Milena J. SCHANK ${ }^{1}$, Aurora MURGEA ${ }^{2}$, Cosmin ENACHE ${ }^{3}$
}

DOI: 10.1515/tjeb-2017-0011

\begin{abstract}
A consistent body of research is dedicated to the relationship between the ownership structure of a firm and its financial performance. Despite that, the hitherto researches fail to reach a consensus regarding this issue since both negative and positive relationships have been found out. This paper examines the impact of ownership's type (more precise the impact of the family ownership) on the firm's financial performance. The analysis includes a comparison between family and non-family firm performance using a sample of 1,161 Romanian companies and 1,342 German companies for a time frame that range between 2008 to 2015. Based on different types of static panel data regressions: Pooled Ordinary Least Squares (OLS), Fixed Effects (FE), Random Effects (RE) and a corrective model (PCSE), the main findings show very different results for the two considered countries. Financial performance, expressed as return on assets (ROA) and return on equity (ROE) seems to be insensitive to family ownership in Romanian companies and statistically positively correlated with it for German ones. A potential explanation for these outputs consists in the different development circumstances in the two countries in the period that forego the Second War. At the same time, other variables considered do not show significant differences in outcome between the two countries: size, age, capital intensity and leverage negatively influence the financial performance of companies.
\end{abstract}

\section{Keywords: $\quad$ Family ownership, financial performance, Control}

\section{JEL Classification: G32, G34, L25}

\footnotetext{
1 PhD, Faculty of Economics and Business Administration, West University of Timisoara, Romania

2 Professor PhD, Faculty of Economics and Business Administration, West University of Timisoara, Romania

3 Professor PhD, Faculty of Economics and Business Administration, West University of Timisoara, Romania
} 
Schank, M.-J., Murgea, A., Enache, C. (2017).

\section{Introduction}

Family firms are the predominant form of business around the globe, key economic and social actors both in developed and developing countries with a major role contributing to gross national product and jobs creation (Astrachan and Shanker, 2003; IFERA, 2003; Zahra and Sharma, 2004). Due to the increasing number and significance of family firms throughout the global economy, understanding the factors that influence their performance become an important goal of the latest researches (Sciascia and Mazzola, 2008; Mazzi, 2011).

As a result of the ubiquity and economic significance of the family business one could wonder if they perform differently than the non-family business. The core difference between family and non-family business is the governance structure of the firm that influence the organizational outcome. Two apparently opposed theories have been proposed to address this issue: agency theory and stewardship theory (for a very detailed review regarding the agency and stewardship theory see Madison et al., 2016). Even if originally agency problems was not expected in family business (Ross, 1973, 1974), due to the apparent alignment between interests, the further researchers point out that asymmetric altruism and executive entrenchment (Block, 2012) or conflicts, such as those stemming from the family-nonfamily shareholder relationship (Ali et al., 2007) make the family business also susceptible to be affected by the agency theory. A very important distinctive element between the agency theory and the stewardship theory regards the way the manager is seen. In the agency theory, the manager is seen as a self-serving person who decides the economic model of a man. On the other side, the stewardship theory (Davis et al., 1997) sees the manager as other-serving man, following the humanistic model of a man present in sociology and psychology. As a result, principals will enact governance mechanisms that create an environment that empowers and fosters this steward behavior and increase the firm's performance (Davis et al., 1997).

Entering deeper and analyzing the effects of a family ownership on financial performances, the prior literature does not reach a consensus (Westhead and Howorth, 2006; Le BretonMiller and Miller, 2008; Ramos et al., 2016). One strand in the literature mainly points out that founding family ownership seems to be less profitable than the dispersed one because combining ownership and control allows concentrated shareholders to exchange profits for private rents (Fama and Jensen, 1983), draw resources away from profitable projects due to a choose of a non-pecuniary consumption (Demsetz, 1983), extracting private benefits from the firm (Shleifer and Vishny, 1997), expropriation of minority shareholders (Bertrand et al., 2002) limit senior management positions to their family members (Morck et al., 2000). On the other side, other studies, point out that the family owned business have obtained better financial performance than non-family one due to several reasons as: the classic ownermanager conflict in non-family firms could be consistently more costly than the conflict between family and non-family shareholders in founder-CEO firms (Villalonga and Amit, 
Schank, M.-J., Murgea, A., Enache, C. (2017).

2006), family firms' proactive marketing behavior and their high emphasis on corporate social responsibility increase financial performance (Kashmiri and Mahajan, 2014), the unique abilities of the funders who also have a CEO position represent a strong competitive advantage with positive effects on financial performance (Anderson and Reeb, 2003).

Each country has its own cultural features, regulatory context and business history, and therefore, in the light of the contingent theory (Hofer, 1975; Ginsberg and Venkatraman 1985), there is no universal set of strategies for all businesses and firms. Analysis conducted in other historical period, other countries and other environmental context are prone to fallacies if they are applied to explain the correlation between family ownership and financial performances worldwide. A customized strategy has to be designed with specific environmental features. In this context, according to our knowledge, the hitherto literature does not include any study that regards the correlation between family ownership and financial performances in Romania. Family-owned Romanian companies are still very young compared with the ones from the developed European countries and they clearly show a different pattern due to cultural features and communist history. In this context a comparative approach with a developed country could also provide hints about the impact of business history heritage on the relation between family ownership and financial performance.

In this regard, the main purpose of this research is to investigate the possible differences in firm performance between family firms and non-family firms in Romania and Germany, two very different countries in regard to the economic and political historical context needed to develop and manage the family business. To examine if there is a significant family-effect on firm performance on these two markets, we will look at the following question: does family ownership have a different effect on firm performance in countries with diverse historical background as Romania and Germany?

Based on these considerations, the first section of this paper focusses on the theoretical development and summarizes the most important studies found in the literature. The second section presents the data collection and outlines the used methodology. The fourth section describes the empirical analysis and discussion. The last section concludes.

\section{Literature Review}

In a broad sense, a family firm can be defined as a controlled organization, managed by several family members from the same generation (Shanker and Astrachan, 1996; Lansberg, 1999) or from different generations (Anderson and Reeb, 2003; Gomez-Mejia et al., 2007). The equity percentage owned by the family varies in different definitions present in the literature as one could see in the following table: 
Schank, M.-J., Murgea, A., Enache, C. (2017).

Family Ownership and Firm Performance: Romania versus Germany

Table 1. Definitions of the family firm.

\begin{tabular}{lll}
\hline \multicolumn{1}{c}{ Authors / Year } & \multicolumn{1}{c}{ Definitions of the family firm } \\
\hline 1 & $\begin{array}{l}\text { Holderness \& Sheehan } \\
\text { (1988) }\end{array}$ & $\begin{array}{l}\text { Family firm - a majority shareholder or individual entity holding at least 50.1\% } \\
\text { of the shares }\end{array}$ \\
\hline 2 & Morck et al. (1988) & $\begin{array}{l}\text { Family firm - a member of the founding family who is among the top two } \\
\text { major shareholders }\end{array}$ \\
\hline 3 & La Porta et al. (1999) & $\begin{array}{l}\text { Family firm - a controlling shareholder whose voting rights directly and } \\
\text { indirectly exceed 20\% }\end{array}$ \\
\hline 4 & Anderson \& Reeb (2003) & $\begin{array}{l}\text { Family firm - a fraction of the share capital owned by the founding family and } \\
\text { / or the presence of family members who carry out their activity and hold a } \\
\text { position in the board of directors }\end{array}$ \\
\hline 5 & Barontini \& Caprio (2006) & $\begin{array}{l}\text { Family firm - a family member involved in managing the company's business, } \\
\text { holding 51\% of the voting rights or controlling more than twice the direct } \\
\text { voting right held by the second major shareholder }\end{array}$ \\
\hline 6 & Villalonga \& Amit (2006) & $\begin{array}{l}\text { Family firm - the presence of a founder or family member in the company's } \\
\text { decision-making process, holding at least 5\% of the company's capital }\end{array}$ \\
\hline 7 & Gomez-Mejia et al. (2007) & Family firm - the company is owned and managed by the founding family \\
\hline 8 & Shyu, J. (2011) & $\begin{array}{l}\text { Family firm - an institution where the total ownership holdings of either family } \\
\text { members or the companies established by the same family exceed 10\% }\end{array}$ \\
\hline
\end{tabular}

The shares owned by the founding family members are a powerful "tool" through which the company can reduce agent costs, and so, increase its performance. Typically, members of the founding family invest most of their wealth in the company, presenting a poorly diversified palette of their interests. They have strong incentives to increase the well-being and performance of the company, ensuring adequate and close monitoring of management decision. Moreover, due to the long-term presence of the founding family or its members in the ownership structure a further benefit would be the high level of knowledge regarding the market and the activity itself.

In this respect, there are numerous studies that focus on the association between family ownership and its effects and company performance. Even if in the first studies, Berle and Means (1932) and Jensen and Meckling (1976) argue that family ownership stimulates the growth of companies' performance, family business has also some inconveniences that affect the performance of the company: different restrictions on the acquisition of capital, some intergenerational conflicts due to different visions and objectives, nepotism, etc. (Schulze et al., 2001, 2003; Gomez-Mejia et al., 2003; Pérez-González, 2006).

Thus, the results of the studies found in the literature on this topic may be grouped according to the nature of the relationship established between the two variables as positive, negative or insignificant. Also there are some studies which point out a non-linear relationship between the two variables and offer arguments for an inverted $U$ shape relationship between family ownership and financial performance. 
Schank, M.-J., Murgea, A., Enache, C. (2017).

Among the first empirical studies which point out a positive correlation between family ownership and financial performance, Anderson and Reeb (2003) suggest that the ownership structure of family firms is an efficient organizational structure simply because these companies have a higher performance than non-family companies. Based on the so called "founder effect" (founders can exert a strong influence on the company through unique abilities, leading to considerable performance), Anderson and Reeb (2003) findings show a higher financial performance for companies whose founders also hold the position of CEO (403 companies included in the S\&P 500 index were analyzed). The authors state that the company's performance remains relatively constant only if the descendants of family firm founders retain their position as decision-makers. These conclusions are also supported for the US market by Ehrhardt, Nowak and Weber (2006) in a study that takes into account the evolution of the long-term performance of 124 American companies. Similar, the superior performances of the family firms compared with the "ordinary" companies were found for 13 Western Europe countries (Maury, 2006), France (Sraer and Thesmar, 2007), Germany (Andres, 2008), Chile (Bonilla et al., 2010), Colombia (González et al., 2012).

The effect seems to be even more consistent in turmoil periods according to Kashmiri and Mahajan (2014) or Minichilli et al. (2016). Family firms tend to keep their advertising intensity, rate of new product introduction and high level of corporate social performance despite the recession while the non-family firms have a less proactive marketing behavior and put lower emphasis on corporate social responsibility during turmoil.

An important distinction is made in the literature between founder-controlled firms and firms controlled by descendants. McConaughy and Phillips (1999) observe that consistent with the life-cycle of the family where the early years are characterized by fast growth, the foundercontrolled firms grow faster and invest more in capital assets and research but the descendant-controlled firms seems to be more profitable, exactly because the main investment effort was made prior by the founders (the study was conducted in US using a sample of 90 companies controlled by founders and 57 companies controlled by successors).These conclusions seems not to hold in any conditions since opposite results have been found by other authors. In a pan-European panel study, Barontini and Caprio (2006) state that operational and market performance are higher in companies managed by founder members than in those in which decision-making is assumed by their descendants. Just a year later, in a study that included US companies, Miller et al. (2007) uses alternatives to the definition of family firm, and show that the results of the study fluctuate as circumstances change. Moreover, the authors make a distinction between companies where the only family member involved in managing the activity is its founder and the companies where, besides the founder, several family members or generations are involved. They conclude that those companies that are managed by a single-family member (the founder) have a higher performance compared to those companies where the work is managed by 
Schank, M.-J., Murgea, A., Enache, C. (2017).

Family Ownership and Firm Performance: Romania versus Germany

several family members in addition to the founder. Molly et al. (2010) found no evidence that a firm's profitability is affected by succession.

In contrast, there are studies whose results show a negative influence of the ownership of the family firm on the performance of the companies because the family firm pursues both economic and non-economic objectives (Lee and Rogoff, 1996). For example, in conflict situations, the decision of the manager of a family company, who is also a member of the founding family, will be influenced greatly by feelings, rather than by economic reason (De Vries, 1996), behavior leading to the waste of family resources.

In this respect, the study by Morck et al. (1998) has contradictory results for Canadian companies, which show much lower financial performance. The authors conclude that low performance is the result of reduced involvement of family successors in the decision-making process, the change in their goals over the previous generation, and the minimum investment made in the company's innovation and progress. A few years later, Villalonga and Amit (2006) were investigating companies on the Fortune 500 list for 1994-2000, and considered family firms to have a higher performance only when the founder of the company acts as chief executive officer (CEO) or as chairman of the board of directors, in close cooperation with the general manager. Contrary to Anderson and Reeb (2003), the authors argue that the company's performance may fall if the descendants of the company's founders act as CEO. The same conclusions are also present in Bennedsen et al. (2007) who found out that family successions have a large causal impact on firm performance since the operating profitability on assets dropped by at least four percentages around CEO transition, especially in fastgrowing industries.

In a smaller number of studies addressing the influence of family ownership on the performance of companies, a statistically insignificant relationship between the variable was identified (Chrisman et al., 2004; Górriz \& Fumás, 1996; Jiang \& Peng, 2011; O'Boyle et al., 2012; Tanewski et al., 2003).

Since the family ownership was proven to generate both positive and negative impact in financial performance, a different strand of literature concentrates on the non-linear relationship between the family ownership and financial performance. In the cases when family ownership becomes large enough, in the absence of legal and regulatory laws, this concentration could enhance opportunism and expropriation, may offset the positive effects of the family ownership and an inverted U-shape relationship may appear. If the situation is opposite, the strong legal and regulatory systems provide sufficient protection to maintain the positive effect of the family ownership (Liu et al., 2012). To our knowledge, Pindado et al. (2008) and Garcia et al. (2008) where the first ones who mentioned this type of relationship both studies being conducted using panel data from Western European countries companies. 
Schank, M.-J., Murgea, A., Enache, C. (2017).

Family Ownership and Firm Performance: Romania versus Germany

Nevertheless, in the end, both studies support the idea of a positive impact of family ownership on firm value generally. Despite the non-linear effect, the final positive impact is explained in Pindado et al. (2008) by the superior performances the young family firms have. The performances obtained by young family firms tend to compensate the decreases generated by the ownership concentration from the old ones. The U-shape relationship is also found in Kowalewski et al. (2010) and De Massis et al. (2015).

\section{Data and Methodology}

\subsection{Data}

The impact of family ownership on the financial performances of the largest active companies from Romania and Germany is analyses within a panel data framework. The initial sample comprised 3,000 Romanian and German companies, with data for a period of 9 years (20082016). By removing all the companies and years with missing data, we settled for a final dataset of 1,161 Romanian companies and 1,342 German companies with data for a period of 8 years (2008-2015). The source of data is AMADEUS, platform database of Bureau van Dijk (2017).

The dependent variable describes the financial performance. Past research identified a range of variables as potentially capturing firm performance. However, in this study, firm performance was measured using two variables: return on total assets (ROA) and return on equity (ROE). ROA measures the company's profitability related to its total assets, while ROE denotes the return on the investment of the equity owners.

In order to capture the potential impact of family ownership on financial performance, we constructed a family firm dummy variable (FAMOWN). In line with Anderson and Reeb (2003), Villalonga and Amit (2006), Miller et al. (2007), Andres (2008) and Isakov and Weisskopf (2009) we assigned a value of 1 for companies with a family ownership concentration above 20 percent and a value of 0 for companies with family ownership under this threshold.

An appropriate set of control variables was introduced in the model, in line with the literature on financial performance determinants. The influence of the firm age on the survival and growth of the firm has been long developed in previous literature. Firm age (AGE) is defined as the natural logarithm of the company age since the establishment until the certain year. This measurement is consistent with Andres (2008), Chu (2009) and Choi et al. (2012). Firm size (SIZE) represents the annual absolute change of natural logarithm of total assets. Andres (2008) and Dang and Li (2015) state a positive direct effect of size on the performance because larger firms are likely to be more efficient in asset utilization and benefit more from economies of scale. However, the larger size may also decrease firm's growth, because small companies find easier high growth opportunity. Capital intensity (CAPINT) illustrates the 
Schank, M.-J., Murgea, A., Enache, C. (2017).

characteristic of the industry in which the firm operates and shows the proportion of fixed assets (tangible assets) over total assets. It is argued that firms with intensive capital are likely to suffer lower agency problems. Generally, previous studies find a negative relationship between capital intensity and firm performance (Demsetz and Villalonga, 2001; Gurbuz and Aybars, 2010; Konijn et al., 2011). The leverage (LVRG) measures the proportion of funds provided by creditors to finance the firm's assets and has been proven to have both positive and negative effects in the previous papers (the debts increased proportion could lead to an increased performance due to the lower costs of the debts compared with the equity but in the same time, in certain situations, could generate losses due to the increased bankruptcy risk (Adams et al.,2005; Andres, 2008 and Isakov and Weisskopf, 2009)

The correlation matrix of the variables is illustrated in Appendix 1 and Appendix 2 in the Appendix. For both sets of companies, the correlation coefficients between independent variables are low. Descriptive statistics are given in Appendix 3 and Appendix 4 in the Appendix. It could be noticed that average level of ROA and ROE are quite similar between the two subsamples (Romania and Germany).

\subsection{Methodology}

Based on the analysis of the literature on corporate financial performance determinants, the general form of the financial performance function could be written as follows:

financial performance $=f($ family. ownership, size, age, capital intensity, leverage $)$

First, we will perform a Pooled Ordinary Least Squares (OLS) estimation, using the following general form of a panel model:

$$
Y_{i, t}=\alpha+\beta_{\mathrm{k}} \mathrm{X}_{i, t}+\varepsilon \mathrm{i}, \mathrm{t}
$$

where $Y$ is represented by the dependent variable (ROA, ROE), $\alpha$ is the intercept, $\beta_{k}$ are the slopes of independent variables, $X$ reflects the interest variable (FAMOWN) and the control variables $k$ by $n$ type (SIZE, AGE, CAPINT and LVRG), i denotes the country, $t$ is the time, while $\varepsilon$ it represents the error term, which varies over both firms and time. The estimation results are given in column 1 and 5 of Appendix 3 and Appendix 4, respectively.

In the next step, we assumed that firms have their own intrinsic characteristics which could influence their financial performance and, therefore we estimated a model with individual effects: 
Schank, M.-J., Murgea, A., Enache, C. (2017).

Family Ownership and Firm Performance: Romania versus Germany

$$
Y_{i, t}=\beta_{0}+\beta_{\mathrm{k}} \mathrm{X}_{i, t}+\alpha_{\mathrm{i}}+\varepsilon_{\mathrm{i}, \mathrm{t}}
$$

where $\beta_{0}$ is the intercept and $\alpha$ i represents all the stable characteristics of firms.

In the first instance, we used a model with fixed effects. The validity of the individual effects was confirmed by an F-test (with the null hypothesis that all $\alpha_{i}=0$ ), except for the model which includes the ROE indicator as a measure of performance in Romanian companies. Individual firm effects are useful to capture the unobserved firm-specific variation in a single firm specific intercept. Moreover, this choice will give an additional benefit: controlling for firm individual effects reduces the possible omitted variable bias. The estimation results are given in column 2 and 6 of the same tables. A formal Pesaran's CD test showed evidence of strong cross-sectional dependence. The presence of heteroskedasticity was confirmed by a modified Wald test for groupwise heteroskedasticity. Both tests were reported in lower part of the results tables. Moreover, it is important to handle the autocorrelation problem adequately before the standard errors of the estimated coefficients to be computed.

We also estimated a random effects model, because the number of firms is higher than the number of periods $(\mathrm{N}>\mathrm{T})$. Random effects models imply a random variation across firms, uncorrelated to the explanatory variables. The results are given in column 3 and 7 of Appendix 3 and Appendix 4, respectively. In order to decide between fixed effects and random effects empirical specifications, a Hausman test was employed which has the null hypothesis saying that both estimators are consistent and the alternative that only fixed effects estimator is consistent. The Hausman test showed that fixed effects estimator should be preferred. Tests results were reported in the lower part of the estimation tables. In addition, it is important to identify the autocorrelation problem before the standard errors of the estimated coefficients to be computed. Wooldridge test for autocorrelation pointed out that the null of no first order autocorrelation could not be rejected.

Given the evidence of strong cross-sectional dependence, the presence of heteroscedasticity and autocorrelation, we used Prais-Winsten PCSE procedure as our baseline scenario. The procedure fits linear models when the residuals are not independent and identically distributed, allowing correcting cross-sectional dependence, heteroskedasticity and autocorrelation. Estimation results are given in column 4 and 8 of Appendix 3 and Appendix 4 , respectively.

\section{Results}

Regardless of the chosen independent variable (ROA or ROE), our results for both countries (Romania and Germany) suggest that a greater concentration of family ownership is an associated factor with improved firm performance, consistent with the assumption that this 
Schank, M.-J., Murgea, A., Enache, C. (2017).

Family Ownership and Firm Performance: Romania versus Germany

type of ownership provides closer supervision on the functioning of the company. However, the coefficient of family ownership variable is positive and statistically significant, but there are some differences between the two countries concerning its statistical significance. For our sample of Romanian companies, the coefficient is statistically significant only at $10 \%$. This result could be explained having in mind the relatively small age of Romanian companies (up to 25 years) and the relatively instable economic environment in the past decades. For our sample of German companies, the coefficient is statistically significant at $1 \%$. This could be due to the maturity of German companies (the average age of family companies is 45-50 years) and to a more stable economic environment (German economy had a steady rate of growth in the past decades).

Table 2. Empirical results - Romanian companies.

\begin{tabular}{|c|c|c|c|c|c|c|c|c|}
\hline & \multicolumn{4}{|c|}{ ROA } & \multicolumn{4}{|c|}{ ROE } \\
\hline & (1) & (2) & (3) & (4) & (5) & (6) & (7) & (8) \\
\hline VARIABLES & OLS & $\mathrm{FE}$ & $\mathrm{RE}$ & PCSE & OLS & $\mathrm{FE}$ & $\mathrm{RE}$ & PCSE \\
\hline FAMOWN & $\begin{array}{l}4.486^{*} \\
(2.667)\end{array}$ & $\begin{array}{c}-1.091^{* * *} \\
(0.199)\end{array}$ & $\begin{array}{l}-0.208 \\
(0.180)\end{array}$ & $\begin{array}{l}1.324^{*} \\
(0.683)\end{array}$ & $\begin{array}{c}4.486^{* * *} \\
(0.812)\end{array}$ & $\begin{array}{c}-4.365^{* * *} \\
(1.310)\end{array}$ & $\begin{array}{c}1.297 \\
(1.061)\end{array}$ & $\begin{array}{l}4.486^{\star} \\
(2.667)\end{array}$ \\
\hline SIZE & $\begin{array}{c}-3.348^{* * *} \\
(0.584)\end{array}$ & $\begin{array}{c}1.649^{* * *} \\
(0.199)\end{array}$ & $\begin{array}{c}-0.657^{* * *} \\
(0.114)\end{array}$ & $\begin{array}{c}-1.447^{* * *} \\
(0.161)\end{array}$ & $\begin{array}{c}-3.348^{* * *} \\
(0.456)\end{array}$ & $\begin{array}{c}7.318^{* * *} \\
(1.309)\end{array}$ & $\begin{array}{c}-2.819^{* * *} \\
(0.499)\end{array}$ & $\begin{array}{c}-3.348^{* * *} \\
(0.584)\end{array}$ \\
\hline AGE & $\begin{array}{c}-0.119 \\
(0.0796)\end{array}$ & $\begin{array}{c}-0.269^{* * *} \\
(0.0368)\end{array}$ & $\begin{array}{l}-0.120^{* * *} \\
(0.0248)\end{array}$ & $\begin{array}{c}-0.123^{* * *} \\
(0.0246)\end{array}$ & $\begin{array}{c}-0.119^{* * *} \\
(0.078)\end{array}$ & $\begin{array}{c}-0.802^{* * *} \\
(0.242)\end{array}$ & $\begin{array}{l}-0.123 \\
(0.114)\end{array}$ & $\begin{array}{c}-0.119^{* * *} \\
(0.078)\end{array}$ \\
\hline CAPINT & $\begin{array}{c}-32.89^{* * *} \\
(3.416)\end{array}$ & $\begin{array}{c}-13.44^{* * *} \\
(0.753)\end{array}$ & $\begin{array}{c}-12.22^{* * *} \\
(0.557)\end{array}$ & $\begin{array}{c}-8.963^{* * *} \\
(1.094)\end{array}$ & $\begin{array}{c}-32.89^{* * *} \\
(2.579)\end{array}$ & $\begin{array}{c}-42.86^{* * *} \\
(4.966)\end{array}$ & $\begin{array}{c}-37.07^{* * *} \\
(2.669)\end{array}$ & $\begin{array}{c}-32.89^{* * *} \\
(3.416)\end{array}$ \\
\hline LVRG & $\begin{array}{c}-20.85^{* * *} \\
(5.408)\end{array}$ & $\begin{array}{c}-25.13^{* * *} \\
(0.640)\end{array}$ & $\begin{array}{c}-21.40^{* * *} \\
(0.533)\end{array}$ & $\begin{array}{c}-17.96^{* * *} \\
(1.665)\end{array}$ & $\begin{array}{c}-20.85^{* * *} \\
(3.531)\end{array}$ & $\begin{array}{c}-58.51^{* * *} \\
(4.217)\end{array}$ & $\begin{array}{c}-29.17^{* * *} \\
(2.764)\end{array}$ & $\begin{array}{c}-20.85^{* * *} \\
(5.408)\end{array}$ \\
\hline Constant & $\begin{array}{c}73.47^{* * *} \\
(6.484)\end{array}$ & $\begin{array}{c}15.42^{* * *} \\
(1.760)\end{array}$ & $\begin{array}{c}32.34^{* * *} \\
(1.116)\end{array}$ & $\begin{array}{c}35.98^{* * *} \\
(1.640)\end{array}$ & $\begin{array}{c}73.47^{* * *} \\
(4.812)\end{array}$ & $\begin{array}{c}10.70 \\
(11.60)\end{array}$ & $\begin{array}{c}76.28^{* * *} \\
(5.180)\end{array}$ & $\begin{array}{c}73.47^{* * *} \\
(6.484)\end{array}$ \\
\hline R-squared & 0.056 & 0.185 & 0.169 & 0.229 & 0.056 & 0.033 & 0.021 & 0.056 \\
\hline F-test all $\alpha \mathrm{i}=0$ & & $8.62^{* * *}$ & & & & $2.84^{* * *}$ & & \\
\hline Hausman test & & & $342.39^{* * *}$ & & & & $169.45^{* * *}$ & \\
\hline Pesaran CD test & & $50.160^{* * *}$ & & & & $34.922^{* * *}$ & & \\
\hline Modified Wald $x 2$ & & $2,100,000^{* * *}$ & & & & $\begin{array}{c}39,000,00 \\
0^{* * *}\end{array}$ & & \\
\hline Wooldridge (F - test) & & $193.981^{* * *}$ & & & & $9.262^{* * *}$ & & \\
\hline Observations & 9,288 & 9,288 & 9,288 & 9,288 & 9,288 & 9,288 & 9,288 & 9,288 \\
\hline Number of groups & & 1,161 & 1,161 & 1,161 & & 1,161 & 1,161 & 1,161 \\
\hline
\end{tabular}

Robust standard errors in parentheses

$* * *, * *$, and * show significance at 1\%,5\% and 10\% level of significance, respectively.

Source: Author's estimations

Among the control variables, in both countries, the variables SIZE and AGE had significant, negative relationships with the company's performance (ROA, ROE), thus, supporting earlier findings from Amato and Burson (2007), Coad et al. (2007), Becker et al. (2010) and Dogan 
Schank, M.-J., Murgea, A., Enache, C. (2017).

Family Ownership and Firm Performance: Romania versus Germany

(2013). This can be explained that while companies become larger and older, they tend to invest in different business that may harm their core business. CAPINT indicates a negative impact on both forms of performance representation of companies, statistically significant at 1\% level, in accordance with Güner et al. (2008). This shows that Romanian and German companies with a high capital intensity ratio register lower financial performance. Finally, LVRG, the last control variable considered, had a significant, negative relationship with company's financial performance. Empirical evidence from previous studies found also a negative relationship between these two variables (Daskalakis and Psillaki, 2008; Vasiliou et al., 2009) and argue that profitable firms are likely to have more retained earnings and do not depend as much on external finance.

Table 3. Empirical results - German companies.

\begin{tabular}{|c|c|c|c|c|c|c|c|c|}
\hline & \multicolumn{4}{|c|}{ ROA } & \multicolumn{4}{|c|}{ ROE } \\
\hline & (1) & (2) & (3) & (4) & (5) & (6) & (7) & (8) \\
\hline VARIABLES & OLS & $\mathrm{FE}$ & RE & PCSE & OLS & FE & $\mathrm{RE}$ & PCSE \\
\hline FAMOWN & $\begin{array}{c}1.457^{* * *} \\
(0.129)\end{array}$ & $\begin{array}{c}0.801^{* * *} \\
(0.295)\end{array}$ & $\begin{array}{c}1.118^{* * *} \\
(0.211)\end{array}$ & $\begin{array}{c}1.457^{* * *} \\
(0.090)\end{array}$ & $\begin{array}{l}2.773^{* *} \\
(1.127)\end{array}$ & $\begin{array}{l}4.378^{* *} \\
(2.118)\end{array}$ & $\begin{array}{l}3.309 * * \\
(1.669)\end{array}$ & $\begin{array}{c}2.773^{* * *} \\
(0.839)\end{array}$ \\
\hline SIZE & $\begin{array}{c}-0.135^{* * *} \\
(0.044)\end{array}$ & $\begin{array}{c}1.441^{* * *} \\
(0.246)\end{array}$ & $\begin{array}{l}0.0478 \\
(0.094)\end{array}$ & $\begin{array}{c}-0.135^{* * *} \\
(0.039)\end{array}$ & $\begin{array}{c}-1.929^{* * *} \\
(0.346)\end{array}$ & $\begin{array}{l}7.474^{* * *} \\
(1.765)\end{array}$ & $\begin{array}{l}-0.773 \\
(0.796)\end{array}$ & $\begin{array}{c}-1.929^{* * *} \\
(0.268)\end{array}$ \\
\hline AGE & $\begin{array}{c}-0.00269^{* *} \\
(0.001)\end{array}$ & $\begin{array}{c}-0.159^{* * *} \\
(0.023)\end{array}$ & $\begin{array}{c}-0.00511 \\
(0.003)\end{array}$ & $\begin{array}{c}-0.00269^{* * *} \\
(0.001)\end{array}$ & $\begin{array}{c}0.00842 \\
(0.009)\end{array}$ & $\begin{array}{c}-0.768^{* * *} \\
(0.171)\end{array}$ & $\begin{array}{c}-0.00953 \\
(0.028)\end{array}$ & $\begin{array}{c}0.00842 \\
(0.007)\end{array}$ \\
\hline CAPINT & $\begin{array}{c}-5.857^{* * *} \\
(0.272)\end{array}$ & $\begin{array}{c}-10.96^{* * *} \\
(0.809)\end{array}$ & $\begin{array}{c}-7.941^{* * *} \\
(0.495)\end{array}$ & $\begin{array}{c}-5.857^{* * *} \\
(0.623)\end{array}$ & $\begin{array}{c}-24.33^{* * *} \\
(1.942)\end{array}$ & $\begin{array}{c}-24.36^{* * *} \\
(5.809)\end{array}$ & $\begin{array}{c}-28.37^{* * *} \\
(4.022)\end{array}$ & $\begin{array}{c}-24.33^{* * *} \\
(3.824)\end{array}$ \\
\hline LVRG & $\begin{array}{c}-9.326^{* * *} \\
(0.373)\end{array}$ & $\begin{array}{c}-18.83^{* * *} \\
(0.708)\end{array}$ & $\begin{array}{c}-13.44^{* * *} \\
(0.509)\end{array}$ & $\begin{array}{c}-9.326^{* * *} \\
(0.840)\end{array}$ & $\begin{array}{c}-18.76^{* * *} \\
(4.625)\end{array}$ & $\begin{array}{c}-63.14^{* * *} \\
(5.085)\end{array}$ & $\begin{array}{c}-26.39^{* * *} \\
(3.993)\end{array}$ & $\begin{array}{c}-18.76^{* * *} \\
(4.986)\end{array}$ \\
\hline Constant & $\begin{array}{c}13.95^{* * *} \\
(0.605)\end{array}$ & $\begin{array}{l}8.982^{* * *} \\
(2.710)\end{array}$ & $\begin{array}{l}15.22^{* \star *} \\
(1.199)\end{array}$ & $\begin{array}{c}13.95^{* * *} \\
(0.481)\end{array}$ & $\begin{array}{l}35.40^{* * *} \\
(3.801)\end{array}$ & $\begin{array}{c}0.249 \\
(19.47)\end{array}$ & $\begin{array}{c}50.83^{* * *} \\
(10.11)\end{array}$ & $\begin{array}{c}35.40^{* * *} \\
(3.470)\end{array}$ \\
\hline R-squared & 0.112 & 0.086 & 0.081 & 0.112 & 0.026 & 0.019 & 0.013 & 0.026 \\
\hline F-test all $\alpha \mathrm{i}=0$ & & $14.86^{* * *}$ & & & & $5.85^{* * *}$ & & \\
\hline Hausman test & & & $165.48^{* * *}$ & & & & $141.63^{* * *}$ & \\
\hline Pesaran CD test & & $27.419^{* * *}$ & & & & $26.635^{* * *}$ & & \\
\hline Modified Wald X2 & & $\underset{* *}{6,700,000^{*}}$ & & & & $\underset{0^{* * *}}{210,000,00}$ & & \\
\hline Wooldridge (F - test) & & $33.922^{* * *}$ & & & & $12.544^{* * *}$ & & \\
\hline Observations & 10,736 & 10,736 & 10,736 & 10,736 & 10,736 & 10,736 & 10,736 & 10,736 \\
\hline Number of groups & & 1,342 & 1,342 & 1,342 & & 1,342 & 1,342 & 1,342 \\
\hline
\end{tabular}


Schank, M.-J., Murgea, A., Enache, C. (2017).

\section{Conclusions}

Using panel data analysis for two consistent samples of Romanian and German companies, we showed that family ownership is one of the factors which enhance financial performance. These results proved to be robust to various estimation methods and to different measures of financial performance (ROA and ROE).

Since the most part of the empirical studies on family ownership and financial performance were performed on samples of companies form developed economies, our research adds to the literature especially by testing this relationship for a consistent sample of Romanian companies. For a former communist country, the conclusion of this study could be particularly useful both at micro and macroeconomic level. At microeconomic level the correlation between family-owned business and financial performance could be a further incentive to expand and develop the existing family businesses. At the macro-economic level it could represent a good governmental incentive to design and implement regulations able to provide a healthy business environment for those companies that could allow them to obtain a constant, solid growth.

The link between family ownership and financial performance proved to be somehow relatively weaker for Romanian companies than for German companies. However, this particular result should be treated carefully, given the significant difference in the company age (the average age is 14.13 years for Romanian companies, and respectively, 44.82 years for German companies).

Not least, further research is needed in order to differentiate between the types of family ownership: founding generation vs. further generations or active ownership (the family owners are also executives) vs. passive ownership (the family owners delegate executive responsibilities to other professionals). 
Schank, M.-J., Murgea, A., Enache, C. (2017).

Family Ownership and Firm Performance: Romania versus Germany

\section{Appendix}

Appendix 1: Matrix of correlations - Romanian companies

\begin{tabular}{c|ccccccc} 
& ROA & ROE & FAMOWN & SIZE & AGE & CAPINT & LVRG \\
\hline ROA & 1.000000 & & & & & & \\
ROE & 0.556090 & 1.000000 & & & & & \\
FAMOWN & 0.102215 & 0.080723 & 1.000000 & & & & \\
SIZE & -0.225433 & -0.148034 & -0.175222 & 1.000000 & & & \\
AGE & -0.031598 & -0.012022 & 0.261283 & 0.136446 & 1.000000 & & \\
CAPINT & -0.208658 & -0.191552 & -0.122385 & 0.313231 & 0.072166 & 1.000000 & \\
LVRG & -0.304131 & -0.035737 & 0.022649 & -0.180798 & -0.172245 & -0.241652 & 1.000000
\end{tabular}

Source: Author's estimations

Appendix 2: Matrix of correlations - German companies

\begin{tabular}{c|ccccccc} 
& ROA & ROE & FAMOWN & SIZE & AGE & CAPINT & LVRG \\
\hline ROA & 1.000000 & & & & & & \\
ROE & 0.540116 & 1.000000 & & & & & \\
FAMOWN & 0.132733 & 0.038719 & 1.000000 & & & & \\
SIZE & -0.112094 & -0.097987 & -0.170356 & 1.000000 & & & \\
AGE & -0.017659 & -0.007344 & 0.031659 & 0.184229 & 1.000000 & & \\
CAPINT & -0.183633 & -0.137537 & -0.084869 & 0.392667 & 0.033818 & 1.000000 & \\
LVRG & -0.228425 & 0.082385 & -0.048158 & -0.054756 & -0.028778 & -0.145134 & 1.000000
\end{tabular}

Source: Author's estimations

Appendix 3: Descriptive statistics - Romanian companies

\begin{tabular}{ccccccc}
\hline & ROA & ROE & SIZE & AGE & CAPINT & LVRG \\
\hline Mean & 6.29 & 14.73 & 9.57 & 14.13 & 0.42 & 0.59 \\
Median & 4.33 & 12.64 & 9.44 & 15.00 & 0.42 & 0.61 \\
Maximum & 69.61 & 651.84 & 16.08 & 25.00 & 0.99 & 0.99 \\
Minimum & -80.20 & -966.88 & 4.75 & 0.00 & 0.00 & 0.02 \\
Std. Dev. & 9.36 & 44.54 & 1.33 & 5.74 & 0.24 & 0.21 \\
Skewness & 0.99 & -8.00 & 0.57 & -0.27 & 0.09 & -0.31 \\
Kurtosis & 9.12 & 158.67 & 4.07 & 2.11 & 2.08 & 2.31 \\
Jarque-Bera & 16035.76 & 9477949.9 & 951.27 & 416.46 & 339.01 & 337.29 \\
Probability & 0.00 & 0.00 & 0.00 & 0.00 & 0.00 & 0.00 \\
Observations & 9288 & 9288 & 9288 & 9288 & 9288 & 9288 \\
\hline
\end{tabular}

Source: Author's estimations 
Schank, M.-J., Murgea, A., Enache, C. (2017).

Family Ownership and Firm Performance: Romania versus Germany

\section{Appendix 4: Descriptive statistics - German companies}

\begin{tabular}{ccccccc}
\hline & ROA & ROE & SIZE & AGE & CAPINT & LVRG \\
\hline Mean & 4.44 & 13.82 & 12.77 & 44.82 & 0.40 & 0.61 \\
Median & 3.67 & 10.37 & 12.53 & 28.50 & 0.38 & 0.63 \\
Maximum & 86.70 & 862.65 & 19.76 & 267.00 & 0.99 & 0.99 \\
Minimum & -75.68 & -913.80 & 8.75 & 0.00 & 0.00 & 0.01 \\
Std. Dev. & 6.88 & 53.83 & 1.38 & 41.70 & 0.23 & 0.18 \\
Skewness & 0.70 & 2.50 & 1.11 & 1.54 & 0.24 & -0.35 \\
Kurtosis & 15.67 & 103.92 & 5.26 & 5.20 & 2.28 & 2.72 \\
Jarque-Bera & 72796.48 & 4568079.7 & 4511.66 & 6449.24 & 341.87 & 261.31 \\
Probability & 0.00 & 0.00 & 0.00 & 0.00 & 0.00 & 0.00 \\
Observations & 10736 & 10736 & 10736 & 10736 & 10736 & 10736 \\
\hline
\end{tabular}

Source: Author's estimations

\section{References}

Adams, R. B., \& Mehran, H. (2005). Corporate performance, board structure and its determinants in the banking industry.

Ali, A., Chen, T. Y., \& Radhakrishnan, S. (2007). Corporate disclosures by family firms. Journal of Accounting and Economics, 44, 238-286.

Amato, L. H., \& Burson, T. E. (2007). The effects of firm size on profit rates in the financial services. Journal of Economics and Economic Education Research, 8(1), 67.

Anderson, R. C., \& Reeb, D. M. (2003). Founding-family ownership and firm performance: evidence from the S\&P 500. The journal of finance, 58(3), 1301-1328.

Andres, C. (2008). Large shareholders and firm performance - An empirical examination of founding-family ownership. Journal of Corporate Finance, 14(4), 431-445.

Astrachan, J. H., \& Shanker, M. C. (2003). Family businesses' contribution to the US economy: A closer look. Family business review, 16(3), 211-219.

Barontini, R., \& Caprio, L. (2006). The effect of family control on firm value and performance: Evidence from continental Europe. European Financial Management, 12(5), 689-723.

Becker-Blease, J. R., Kaen, F., Etebari, A., \& Baumann, H. (2010). Employees, firm size and profitability in US manufacturing industries. Investment Management and Financial Innovations, 7(2), 7-23.

Bennedsen, M., Nielsen, K., Pérez-González, F., \& Wolfenzon, D. (2007). Inside the family firm: The role of families in succession decisions and performance. The Quarterly Journal of Economics, 122(2), 647-691.

Bertrand, M., Mehta, P., \& Mullainathan, S. (2002). Ferreting out tunneling: An application to Indian business groups. Quarterly Journal of Economics, 117(1), 121-148.

Berle, A., \& Means, G. (1932). The modern corporate and private property. New York, NY: McMillian.

Block, J. H. (2012). R\&D investments in family and founder firms: An agency perspective. Journal of Business Venturing, 27, 248-265. 
Schank, M.-J., Murgea, A., Enache, C. (2017).

Family Ownership and Firm Performance: Romania versus Germany

Bonilla, C. A., Sepulveda, J., \& Carvajal, M. (2010). Family ownership and firm performance in Chile: A note on Martinez et al.'s evidence. Family Business Review, 23(2), 148-154.

Bureau van Dijk (2017). AMADEUS platform database of Bureau van Dijk, accessed in June 2017.

Choi, S. B., Park, B., \& Hong, P. (2012). Does ownership structure matter for firm technological innovation performance? The case of Korean firms. Corporate Governance: An International Review, 20(3), 267-288.

Chrisman, J. J., Chua, J. H., \& Litz, R. A. (2004). Comparing the agency costs of family and nonfamily firms: Conceptual issues and exploratory evidence. Entrepreneurship Theory and practice, 28(4), 335-354.

Chu, W. (2009). The influence of family ownership on SME performance: evidence from public firms in Taiwan. Small Business Economics, 33(3), 353-373.

Coad, A., Segarra, A., \& Teruel, M. (2007). Like milk or wine does performance improve with age. The Papers on Economic and Evolution Working Paper 1006.

Dang, C., \& Li, F. (2015). Measuring firm size in empirical corporate finance. SSRN Electronic Journal.

Daskalakis, N., \& Psillaki, M. (2008). Do country or firm factors explain capital structure? Evidence from SMEs in France and Greece. Applied financial economics, 18(2), 87-97.

Davis, J. H., Schoorman, F. D., \& Donaldson, R. (1997). Toward a stewardship theory of management. Academy of Management Review, 22(1), 20-47

De Massis, A., Kotlar, J., Campopiano, G., \& Cassia, L. (2015). The impact of family involvement on SMEs' performance: Theory and evidence. Journal of Small Business Management, 53(4), 924-948.

Demsetz, H. (1983). The Structure of Ownership and the Theory of the Firm. Journal of Law and Economics, 26(2), 375-390.

Demsetz, H., \& Villalonga, B. (2001). Ownership structure and corporate performance. Journal of corporate finance, $7(3), 209-233$.

De Vries, K. M. (1996). Family business: human dilemmas in the family firm: text and cases. Arden Shakespeare.

Dogan, M. (2013). Does firm size affect the firm profitability? Evidence from Turkey. Research Journal of Finance and Accounting, 4(4), 53-59.

Ehrhardt, O., Nowak, E., \& Weber, F.-M. (2006). Running in the family - the evolution of ownership, control, and performance in German family-owned firms 1903-2003. Swiss Finance Institute Research Paper (06-13).

Fama, E. F, \& Jensen, M. C. (1983). Separation of Ownership \& Control. Journal of Law \& Economics, 26(2), 301-326

Górriz, C. G., \& Fumás, V. S. (1996). Ownership structure and firm performance: Some empirical evidence from Spain. Managerial and Decision Economics, 17(6), 575-586

Garcia, J. P., Puerto, I. R., \& de la Torre Olvera, C. (2008). Does family ownership impact positively on firm value? Estableciendo puentes en una economía global. Escuela Superior de Gestión Comercial y Marketing, ESIC.

Ginsberg, A., \& Venkatraman, N. (1985). Contingency perspectives of organizational strategy: a critical review of the empirical research. Academy of Management Review, 10(3), 421434. 
Schank, M.-J., Murgea, A., Enache, C. (2017).

Family Ownership and Firm Performance: Romania versus Germany

Gomez-Mejia, L. R., Haynes, K., Nunez-Nickel, M., Jacobson, K., \& Moyano-Fuentes, J. (2007). Family owned firms: Risk loving or risk averse. Administrative Science Quarterly, 52(1), 106-137.

Gomez-Mejia, L. R., Larraza-Kintana, M., \& Makri, M. (2003). The determinants of executive compensation in family-controlled public corporations. Academy of management journal, 46(2), 226-237.

González, M., Guzmán, A., Pombo, C., \& Trujillo, M. A. (2012). Family firms and financial performance: The cost of growing. Emerging Markets Review, 13(4), 626-649.

Güner, A. B., Malmendier, U., \& Tate, G. (2008). Financial expertise of directors. Journal of Financial Economics, 88(2), 323-354.

Gurbuz, A. O., \& Aybars, A. (2010). The impact of foreign ownership on firm performance, evidence from an emerging market: Turkey. American Journal of Economics and Business Administration, 2(4), 350-359.

Hofer, C. W. (1975). Toward a contingency theory of business strategy. Academy of Management journal, 18(4), 784-810.

Holderness, C. G., \& Sheehan, D. P. (1988). The role of majority shareholders in publicly held corporations: An exploratory analysis. Journal of financial economics, 20, 317-346.

IFERA. (2003). Family businesses dominate. Family Business Review, 16, 235-240

Isakov, D., \& Weisskopf, J.-P. (2009). Family ownership, multiple blockholders and firm performance. Finance International Meeting. AFFI-EUROFIDAI.

Jensen, M. C., \& Meckling, W. H. (1976). Theory of the firm: Managerial behavior, agency costs and ownership structure. Journal of Financial Economics, 3(4), 305-360.

Jiang, Y., \& Peng, M. W. (2011). Are family ownership and control in large firms good, bad, or irrelevant? Asia Pacific Journal of Management, 28(1), 15-39.

Kashmiri, S., \& Mahajan, V. (2014). Beating the recession blues: Exploring the link between family ownership, strategic marketing behavior and firm performance during recessions. International Journal of Research in Marketing, 31(1), 78-93.

Konijn, S. J., Kräussl, R., \& Lucas, A. (2011). Blockholder dispersion and firm value. Journal of Corporate Finance, 17(5), 1330-1339.

Kowalewski, O., Talavera, O., \& Stetsyuk, I. (2010). Influence of family involvement in management and ownership on firm performance: Evidence from Poland. Family Business Review, 23(1), 45-59.

La Porta, R., Lopez-de-Silanes, F., Shleifer, A., \& Vishny, R. (1999). The quality of government. Journal of Law, Economics, and organization, 15(1), 222-279.

Lansberg, I. (1999). Succeeding generations: Realizing the dream of families in business. Harvard Business Press.

Le Breton-Miller, I., \& Miller, D. (2008). To grow or to harvest? Governance, strategy and performance in family and lone founder firms. Journal of Strategy and Management(1), 41-56.

Lee, M.-S., \& Rogoff, E. G. (1996). Research note: Comparison of small businesses with family participation versus small businesses without family participation: An investigation of differences in goals, attitudes, and family/business conflict. Family Business Review, 9(4), 423-437.

Liu, W., Yang, H., \& Zhang, G. (2012). Does family business excel in firm performance? An institution-based view. Asia Pacific Journal of Management, 29(4), 965-987. 
Schank, M.-J., Murgea, A., Enache, C. (2017).

Family Ownership and Firm Performance: Romania versus Germany

Madison, K., Holt, D. T., Kellermanns, F. W., \& Ranft, A. L. (2016). Viewing family firm behavior and governance through the lens of agency and stewardship theories. Family Business Review, 29(1), 65-93.

Maury, B. (2006). Family ownership and firm performance: Empirical evidence from Western European corporations. Journal of Corporate Finance, 12(2), 321-341.

Mazzi, C. (2011). Family business and financial performance: Current state of knowledge and future research challenges. Journal of Family Business Strategy, 2(3), 166-181.

McConaughy, D. L., \& Phillips, M. G. (1999). Founders versus descendants: The profitability, efficiency, growth characteristics and financing in large, public, founding-familycontrolled firms. Family Business Review, 12(2), 123-131.

Miller, D., Le Breton-Miller, I., Lester, R., \& Cannella, A. (2007). Are family firms really superior performers? Journal of Corporate Finance, 13(5), 829-858.

Minichilli, A., Brogi, M., \& Calabrò, A. (2016). Weathering the storm: Family ownership, governance, and performance through the financial and economic crisis. Corporate Governance: An International Review, 24(6), 552-568.

Molly, V., Laveren, E., \& Deloof, M. (2010). Family business succession and its impact on financial structure and performance. Family Business Review, 23(2), 131-147.

Morck, R., Shleifer, A., \& Vishny, R. W. (1988). Management ownership and market valuation: An empirical analysis. Journal of financial economics, 20, 293-315.

Morck, R., Strangeland, D., \& Yeung, B. (2000). Inherited wealth, corporate control, and economic growth: the Canadian disease. In Randall Morck (Ed), Concentrated Corporate Ownership, 319-369, Chicago: University of Chicago Press.

O'Boyle, E. H., Pollack, J. M., \& Rutherford, M. W. (2012). Exploring the relation between family involvement and firms' financial performance: A meta-analysis of main and moderator effects. Journal of Business Venturing, 27(1), 1-18.

Pérez-González, F. (2006). Inherited control and firm performance. The American economic review, 96(5), 1559-1588.

Pindado, J., Requejo, I., \& de la Torre, C. (2008). Does family ownership impact positively on firm value? Empirical evidence from Western Europe. Documento de Trabajo 2, 08.

Ramos, H. M., Buck, W. P., \& Ong, S. L. (2016). The influence of family ownership and involvement on Chinese family firm performance: a systematic literature review. International Journal of Management Practice, 9(4), 365-393.

Ross, Stephen A. (1973). The economic theory of agency: The principal's problem. American Economic Review 62(2): 134-139.

Ross, Stephen A. (1974). On the economic theory of agency and the principle of similarity. In M. Balch, D. McFadden and S. Wu, eds., Essays on economic behavior under uncertainty. North-Holland, ch. 8.

Schulze, W. S., Lubatkin, M. H., Dino, R. N., \& Buchholtz, A. K. (2001). Agency relationships in family firms: Theory and evidence. Organization science, 12(2), 99-116.

Schulze, W. S., Lubatkin, M. H., Dino, R. N., \& Buchholtz, A. K. (2003). Exploring the agency consequences of ownership dispersion among the directors of private family firms. Academy of Management Journal, 46(2), 179-194.

Sciascia, S., \& Mazzola, P. (2008). Family involvement in ownership and management: Exploring nonlinear effects on performance. Family Business Review, 21(4), 331-345.

Shanker, M. C., \& Astrachan, J. H. (1996). Myths and realities: Family businesses' contribution to the US economy - A framework for assessing family business statistics. Family Business Review, 9(2), 107-123. 
Schank, M.-J., Murgea, A., Enache, C. (2017).

Family Ownership and Firm Performance: Romania versus Germany

Shleifer, Andrei and Robert W. Vishny (1997), A Survey of Corporate Governance, The Journal of Finance, 52(2), pp. 737-783.

Shyu, J. (2011). Family ownership and firm performance: evidence from Taiwanese firms. International Journal of Managerial Finance, 7(4), 397-411.

Sraer, D., \& Thesmar, D. (2007). Performance and behavior of family firms: Evidence from the French stock market. Journal of the European Economic Association, 5(4), 709-751.

Tanewski, G. A., Prajogo, D., \& Sohal, A. (2003). Strategic orientation and innovation performance between family and non-family firms. International Council for Small Business.

Vasiliou, D., Eriotis, N., \& Daskalakis, N. (2009). Testing the pecking order theory: the importance of methodology. Qualitative Research in Financial Markets, 1(2), 85-96.

Villalonga, B., \& Amit, R. (2006). How Do Family Ownership, Management, and Control Affect Firm Value? Journal of Financial Economics, 80, 385-417.

Westhead, P., \& Howorth, C. (2006). Ownership and management issues associated with family firm performance and company objectives. Family Business Review, 19(4), 301-316.

Zahra, S. A., \& Sharma, P. (2004). Family business research: A strategic reflection. Family Business Review, 17(4), 331-346. 